Please cite this article as:

Kotzab, Herbert, Munch, Hilde M., de Faultrier, Brigitte, Teller, Christoph. 2011. Environmental Retail Supply Chains: when global Goliaths become environmental Davids. International Journal of Retail \& Distribution Management, 39 (9), pp. 658-681, DOI: $10.1108 / 09590551111159332$. 


\section{ENVIRONMENTAL RETAIL SUPPLY CHAINS: WHEN GLOBAL GOLIATHS BECOME ENVIRONMENTAL DAVIDS}

Herbert Kotzab $^{\mathrm{I}}$, Hilde M. Munch ${ }^{\mathrm{II}}$, Brigitte de Faultrier ${ }^{\mathrm{III}}$, Christoph Teller ${ }^{\mathrm{IV}}$,

I, Copenhagen Business School, Department of Operations Management, Frederiksberg, DK2000, Denmark; Phone: +45 3815 2450, Fax: +45 3815 2973, Email: hk.om@cbs.dk; International Professor, Caledonian Business School, Glasgow Caledonian University

II, Copenhagen Business School, Department of Operations Management, Frederiksberg, DK2000, Denmark; Phone: +45 3815 2450, Fax: +45 3815 2973, Email: hmatre@yahoo.com;

III, [corresponding author] ESSCA School of Management, LUNAM, Angers, France; Phone: +33 2417347 47, Fax: +33 2417347 48, Email: Brigitte.defaultrier@essca.fr;

IV, Surrey Business School, University of Surrey, Guildford, GU2 7XH, England, United Kingdom; 


\title{
Environmental Retail Supply Chains: When global Goliaths become environmental
}

\section{Davids}

\begin{abstract}
Purpose: The purpose of this paper is (1) to develop a scale that evaluates the environmental elements in retail supply chains and (2) to examine the environmental supply chain management initiatives of the world's largest 100 retailing companies.
\end{abstract}

Methodology: The empirical evaluation has been executed through an investigative approach applying a web-scan framework which included the analysis of websites and publicly published documents such as annual reports and Corporate Social Responsibility reports.

Findings: We identified 34 environmental sustainability initiatives which we grouped into eight categories. They refer to 'fundamental environmental attitude', 'use of energy', 'use of input material', 'product', 'packaging', 'transport', 'consumption', and 'waste'. The level of environmental supply chain management can be characterised as very operational and very short-term oriented (= green operations). Long-term oriented green-design-initiatives were hardly observed. Furthermore, the specific environmental activities of three retailers from Denmark, France and the United Kingdom were compared.

Research limitations: The empirical study investigates supply chain operations of retailers and excludes other areas of retail management. The results are based on material that is published by the respective companies and thus do not comprise internal reports.

Value of paper: The main contribution of this paper is to test the proposition that global retailers follow the path of the 'greening Goliaths', where environmental sustainability becomes a quasi industry standard for the ecological sustainability transformation of global retailing

Keywords: Environmental Sustainability, Global Retailing, Supply chain, Environment; 



\section{Environmental Retail Supply Chains: When global Goliaths become environmental Davids}

\section{Introduction}

The focus on being more sensitive to the environment has increased continually over the last few decades. The environmental orientation of corporations is a societal megatrend (Larsen, 2006) that will substantially affect the future management of supply chains, although experts are uncertain about how dire the situation is for our environment. However, there is a common agreement that companies need to reduce their environmental footprint (e.g. Carter and Jennings, 2002).

In March 2009, the European Commission and the European retail sector launched the Retail Forum as part of their drive to promote more environmentally sustainable consumption patterns (European Commission, 2009a). So far, 21 European retailers and 7 federations have joined the forum and work together on the creation of a retailer environmental action plan (REAP) that includes a number of environmental commitments on a company base. In April 2009, the European Commission published its analytical report on 'European' attitudes towards the issue of sustainable consumption and production' (European Commission, 2009b) including strategies retailers and producers can apply in order to promote and to produce environmental friendly products.

Within the United Kingdom, we are able to see the transformation of the retail segment to be "green, healthy and fair" (Jones et al., 2008a) as consumers become progressively more selective of what they buy and from whom they buy these goods, it is important for retailing companies to be aware of their behaviour in society (Jones et al., 2005a). Jönson (1996, 23) points out that "market pressure is increasingly focusing on the environment. This means that 
solving environmental issues in relation to product, service and activity developments ought to lie at the heart of future activities for both governments and industry". However, as Jones et al. (2008b) also points out, retailers, especially large ones, are the gatekeepers for an environmental development in supply chains.

Environmental retail management is therefore not limited to category management or customer relationship management, the management of retail supply chains plays a major role as Jones et al. (2005a) pointed out. Looking at the increasing sales volume of global retail companies, which grew between 2006 and 2009 by more than $10 \%$ to $€ 2.71$ trillion $(\$ 3.8$ trillion) (Deloitte/StoreMedia, 2010) we could presume that these global players can actively use this gate keeper position and positively influence the environmental transformation of their supply chains and markets in which they operate. Taking the notions of Friedman (1970) who points towards the only responsibility of a firm is to increase its profits, the question remains whether or not environmental retail management and especially the environmental management of retailing supply chains pays off. Markley and Davis (2007) have proposed a conceptual framework that the inclusion of sustainability into the management of supply chains is positively related to the profitability of a firm. However, before being able to identify a positive relationship between environmental supply chain management and the profitability of a retailer, it would be necessary to measure a current stage of environmental supply chain engagement.

Consequently we were interested to examine the following research question: How much environmental is the management of the examined retailers? To answer this question we propose an investigative approach (see e.g. Jones et al. 2005a) in order to understand what global retailing companies do practically when it comes to their environmental sustainability. The purpose of this paper is (1) to characterise the environmental efforts in the supply chain 
management of the largest retailers of the world and (2) to investigate to what degree these retailers conform to their environmental responsibility and cope with the megatrend environment in their supply chain activities. We adapt some of the notions of Hockerts and Wüstenhagen (2010) who introduced the 'emerging David' as well as the 'greening Goliath' as two archetypes of environmental companies showing how companies deal with the incorporation of environmental sustainability issues in their business strategies. The main contribution of this paper is to test the proposition that global retailers follow the path of the 'greening Goliaths', where sustainability becomes a quasi industry standard for the environmental sustainability transformation of global retailing (Hockerts and Wüstenhagen, 2010).

The realm of the paper is as follows: After these introductory remarks we develop a methodological framework for environmental retail supply chain management that has been empirically tested. Thereafter the results of our empirical analysis are presented. There we first show the aggregated outcome of our analysis and then portray the environmental approaches of the three selected retailers. The paper concludes with a critical summary of our findings and an outlook for future research.

\section{Environmental retail supply chain management and drivers for environmental sustainability}

Acting in a sustainable manner means for firms to what degree the exploitation of resources, the direction of investments, the orientation of technological development, and institutional change are made consistent with future as well as present needs. For Dunphy et al. (2003) it is the responsibility of the companies of the world to precede in a sustainable manner. To do so, Elkington (1998) or Dyllick and Hockerts (2002) put economic, social and environmental elements together that is also known as the (extended) triple bottom line (e.g. Elkington, 
1998; Dyllick and Hockerts, 2002). Combining these three dimensions leads to different performance outcomes such as eco-efficiency, business ethics or environmental justice (Elkington, 1998). As we see that sustainability is a difficult construct to define and to measure (Faber et al., 2005).Consequently we have chosen to look at the environmental dimension only

Hockerts and Wüstenhagen (2010) discussed the phenomenon of environmental management in general and examined the phenomena of environmental entrepreneurship in particular. Thereby they differed between large corporations (= Greening Goliaths), which implement the environmental agenda into their corporate strategy step by step, and small firms (= Emerging Davids) where the consideration of the environment is the main business model. According to their notions, global retailers fall into the category of 'Greening Goliaths' as these companies are very large and the environmental objective is a complementary element of the main strategy. Their model can also be seen as a diffusion model of sustainable innovation, where at the end of the day, the overall goal is to have a sustainable transformed industry,

Looking at the motivation why companies are getting environmentally engaged, we were able to see the following:

- Legal regulations like waste management, like the Waste Electrical and Electronic Equipment Directive of the European Union (2002/96/EC) that imposes companies to set up an infrastructure for collecting such waste, can also force companies to act green. Even though such systems create additional costs, companies are forced to reduce waste, which in the long run has positive effects on the economic and ecological bottom line. Nakao et al. (2007) have thereby identified a positive relation between the financial and ecological 
sustainability, even though other studies (e.g. Clemens and Papadakis, 2008) doubt the positive effects or claim that this relation cannot be established (Williander, 2007).

- The intrinsic motivation of the entrepreneur or top management of global acting retailers can be a driving force (Lawrence et al., 2006) though critical voices again see the inability of managers to identify green issues as a sound economical business opportunity (Thomas, 2005). Also external stakeholders can influence the environmental attitude of global retailers (Dobers and Wolf, 2000; Larson, 2000 or Masurel, 2007).

- The inclusion of environmental dimensions will become relevant if this leads to a competitive advantage (Regeczi, 2005) because either it shows sufficient return on investment to become green (Hart and Ahuja, 1994) or it leads to a better image of the companies (e.g. Mathis, 2007; Iles, 2008) or it is a customer requirement to be environmentally friendly (Grankvist and Biel, 2007).

Why is this issue for retailing companies? First, consumers want to buy products that do not harm the environment on the other hand these products shall be as cheap as possible, which requires global sourcing (Jones et al., 2005a). Secondly, global retailers can be seen as facilitators of globalisation and consequently they have to deal with the negative impacts of globalisation, such as global warming or the climate change (Halldorsson et al., 2009). Here the Stern Review on the Economics of the Climate Change (2006) showed that a large share of the total emissions of greenhouse gases in the world stem from transportation that links the various nodes of global supply chains.

When transforming a supply chain into an environmental supply chain from a focal company's point of view, Srivastava (2007) suggests the integration of environmental 
thinking into product design, sourcing and supplier selection and the delivery of the final product to its end users as well as into return management. Taking the holistic supply chain view, Braungart et al. (2007) propose the cradle-to-cradle-approach, also known as life cycle assessment that is a technique to assess each and every impact associated with all the stages of a process from raw materials through materials processing, manufacture, distribution, use, repair and maintenance, and disposal or recycling (USEPA, 2010). Based on this, the environmental management of supply chains can then be defined as an input-output process, where resources, materials and energy are the inputs and air emissions, emissions to water, waste, products and co-products are the outputs (e.g. Læntver, 1993).

Jones and colleagues have looked at sustainable retailing in the UK and have presented various insights from their studies:

- Jones et al. (2004) examined the sourcing strategies of British retailers by following the paths of the products. There they were able to see that the sourcing strategies of retailing companies were a blending of local and global sourcing.

- Jones et al. (2005a) confront consumerism with sustainable retailing and show the potential action plans for UK retailers on how to cope with these challenges.

- Jones et al. (2005b) examined the sustainable development of the 20 largest British retailers. While it was easy to find information on corporate social responsibility (CSR), it was difficult to identify the correlation between the economic impact and the level of CSR engagement.

- Jones et al. (2005c) identified for the 10 leading British retailers some CSR Key Performance Indicators and showed that these retailers were very engaged in environmental 
activities such as reducing energy and waste. Again, the level of information provided by the examined retailers differed.

- Jones et al. (2007a) examine the corporate social responsibility attitude of ten global retailers. Thereby they identify limitations in gathering data and limitations in the validity of the presented information as retailing companies do not report in a standardised manner on their CSR.

- The examination of CSR within food retailing was the purpose of Jones et al. (2007b). Again, the authors identify that the examination only offers a snapshot of CSR as the level of information provided by the retailing companies differed significantly.

- Jones et al. (2008a) discuss the work of the Sustainable Development Commission and the consequences for British retailing. There, the authors see difficulties on how retailers may align their business strategies with such policy making.

- The Jones et al. (2008b) study proposes three scenarios on how British retailers may realise sustainable development in their business strategies. The sustainability level ranges in these scenarios significantly and show the dilemma for retailers when becoming sustainable. Many players follow a cost leadership strategy, whereas sustainability would rather be part of a differentiation strategy.

Based on the presented theoretical and empirical notions, we can develop a framework of environmental retail supply chain management consisting of eight categories (see Table $1)$. 


\section{Investigative approach}

Following the methodological suggestion of Jones et al. (2005a) and Kotzab and Madlberger (2001), we applied an investigative web-scan approach in order to gain particular insight into the environmental supply chain management activities of the world's 100 largest retailing companies as documented by the Deloitte/Stores Media (2008) 'Global Power of Retailing' study. We presumed that these retailing companies use their Internet websites to provide information on environmental issues through their annual reports, CSR reports and articles on the environment which would be available to the public. This view has been confirmed by Biloslavo and Trnavcevic (2009) who identified web-sites as communication tool for companies while transforming into green companies.

Due to a lack of language capabilities, eight retailers which only provided their website in their national language were excluded from the sample. Based on the remaining sample of 92 retailing companies, we analyzed the information provided on their websites as well as a total of 68 annual reports, 36 CSR reports and 36 other published documents. The documents were gathered in two waves, where we also scanned the websites twice.

Based on the gathered data, we were able disaggregate the eight general environmental supply chain categories into a number of specific environmental supply chain activities. Based on these findings we then developed an environmental sustainability scale ranging from 'no environmental sustainability at all' to 'full environmental sustainability' depending on the number of accomplished initiatives. It is necessary to note that our approach aimed towards the nature of environmental sustainable initiatives and not on the quality of those. Our analysis is therefore not judgmental in the sense of giving an opinion on how well the retailers 
are performing their environmental activities. However, the number of identified initiatives may give an indication on the willingness to act environmentally sustainable.

\section{Results}

\subsection{Overall range of environmental engagement}

Table 2 shows the overall results of our analysis, where we were able to split our eight categories, based on the empirical observations, into 34 environmental supply chain activities.

\section{Table 2 near here}

'Encouragement of environmental responsibility and continuous improvement in the supply chain' has been identified as the most reported initiative although it is basically not a direct practical environmental initiative. It is not surprising that retailers indicate their attitude towards the environment publicly in regards to a so-called environmental correctness. The second most frequently mentioned environmental initiative deals with the reduction of energy and resource consumption in their buildings $(2 \mathrm{~A})$. The third and fourth most frequently implemented environmental initiatives cover both the retailers' (8A) and customers' (8C) handling of waste and materials for recycling. The fifth most frequently observed environmental initiative was cooperation with other companies and organisations for environmental initiatives (1B) which is truly a supply chain issue. At the bottom of the identified initiatives we see that the least reported initiative is the one on customisation of product design for lower energy consumption by use of the product (4C).

The five most often identified environmental initiatives belong to the categories 'fundamental environmental attitude', 'packaging' and 'use of energy' while the bottom 5 initiatives belong to the 'product' dimension, 'transport', 'use of energy', 'use of input material' and 
'fundamental environmental attitude'. There retailers may be able to set requirements for the product so that it supports the company's strategy for the environment. The second least often monitored environmental initiative deals with, which only ten retailers reported was the category on improving the production equipment in relation to used energy and resource consumption (2C). The third least observed initiative is in the planning of the size of product packaging to better utilise storage and transport (6B) although an implementation of this initiative can result in saving many transport kilometres each year.

Surprisingly, the next initiative is in regards to using more local produce, both for the benefit of local production, but also to conserve the environment by saving on transportation mileage (3C). The fifth least-priority environmental initiative is the support of environmental projects (1C).

\subsection{Development of an environmental sustainability scale}

The overall analysis showed that that none of the examined retailing companies has completed the full set of environmental supply chain activities (see Table 3). Additionally we identify a number of companies that reported no initiatives at all. In total, we can observe that more than a half of the examined retailing companies fall into the category 'average environmental sustainability' or 'above average environmental sustainability' (see Figure 1).

Figure land Table 3 near here

To highlight these results, Table 4 compares the top end with the bottom end of the examined retailers. 
We can see that UK-based companies provide considerable amount of information about their environmental efforts, while mainly US-based and German retailers are positioned at the bottom end since these companies report no environmental activity at all. As most of the reported initiatives show a short term character, we labelled them as 'green operation initiatives'. These activities seem to be easy to initiate and execute as well as show immediate positive effects on the economic as well as environmental bottom line. Retailers that show a higher environmental sustainability level seem to have already invested more into longer term oriented activities that we labelled as 'green design initiatives'.

However, environmental supply chain management - just like sustainability as itself - is difficult to implement and measure but easy to understand and be demanded (Brunvoll, 2008). Therefore the current stage of environmental supply chain management that the largest global retailers are publicly demonstrating is quite sobering.

Following the notions of Hockerts and Wüstenhagen (2010) global retailers seems far away from a quasi-industrial standard for environmental supply chain management. Still, the examined companies focus on economic objectives and - because of their dominance in their operating markets - those Goliaths need to incorporate environmental sustainability into their supply chain strategies and operations. This seems to be done in a step by step mode when looking at the top-performing range of organisations. From this point of view, and altering the notions of Hockerts and Wüstenhagen (2010), the 'Greening Goliaths' convert to 'EcoDavids' as their environmental objectives are not on the same importance level as their economic objectives.

In order to strengthen this argument and to further develop our scale as well as to provide additional interpretation and consequently a more comprehensive understanding of the results 
from the frequency counts of our investigative approach, we expanded the investigative approach by examining the data from French Carrefour, Danish Coop and British Marks and Spencer. With this we also want to gain more insight into the environmental (supply chain) activities and consequently identify potential country-related differences. Our analysis shows that these three companies scored best when it comes to a country specific analysis (see Table 3). Carrefour and Marks and Spencer can be classified as above average environmental sustainability (see also Table 5), while Coop with its 16 initiatives represents an average score when it comes to environmental retail supply chain management.

\section{Environmental retail supply chain management in selected case companies}

In order to make a meaningful comparison we analyzed the fundamental sustainability attitude, environmental and ecological activities, the carbon footprint initiatives, sustainable supplier relationships and the return on ecology which we then put into an overall evaluation.

\subsection{Carrefour ${ }^{1}$}

\subsubsection{General information on the company}

Carrefour is the world's second largest retailer and the largest multiple format retailer in Europe. With more than 475,000 people employed in 33 countries, it generates a turnover of EUR 96.2 billion (2009) with $43 \%$ of its sales in France, its country of origin. Carrefour has developed a multi format store strategy in more than 15,500 stores which includes hypermarkets (leading stores with $59 \%$ of the global turnover), supermarkets, hard-discounts, convenience stores and cash and carry outlets.

\footnotetext{
${ }^{1}$ This section refers to Carrefour (2009) and Carrefour (2010)
} 


\subsubsection{Fundamental attitude towards sustainability}

French Carrefour is an international retailer with a desire to be central to local economic development where it has a presence. Today 90 to $95 \%$ of the products put on shelves are provided by local producers or growers. Carrefour was a pioneer in putting into action the principles of sustainability by launching in 1992 the "Carrefour Quality Lines" for fresh products. These 420 lines are based on an upstream approach with suppliers, who are remunerated for their efforts on quality with long term partnerships, promotion of local knowhow and integrated farming.

Carrefour formalised its sustainability initiatives when an autonomous Directorate in Sustainability was established in 2001 and its intention to work in sustainable relationships by defining its core values in 2002. These were liberty, responsibility, sharing, respect, integrity, solidarity and progress which are still central to their operation today.

\subsubsection{Environmental and ecological activities}

Carrefour developed a project for fair trade "to assume all its responsibilities from the producer to the consumer and give priority to a constructive dialogue with its stakeholders". Its project is operationalised each year by defining the actions which it considered to be key objectives. In 2008, the actions have concentrated on food balance, responsible consumption, social conditions of producing, responsible employer and environmental footprint.

To help consumers to look for responsibly produced products, Carrefour offers many different types of this kind of products: a range of 329 organic products under the brand Carrefour Bio, 621 products from Fair Trade (Carrefour AGIR Solidaire - ACT Fair) and a range of products 
Carrefour AGIR Eco Planète (ACT Eco Planet) which have been produced with minimal impact on the environment.

\subsubsection{Carbon footprint ${ }^{1}$}

Carrefour is largely engaged in the reduction of greenhouse gas emissions and in the fighting of climate change. A program of Energy Efficiency was launched in 2007 to save energy in the stores by many improvements. An investment of EUR 30 million in 2008 contributed to reducing global group consumption by $13.6 \%$, compared to 2004 .

Carrefour has also been working on the efficiency of its supply chain to reduce emissions. Thus, efforts have been made to optimise store delivery. The objective of $45 \%$ of imported merchandise transported by inland waterway and railway transportation was achieved by the middle of 2009 for a saving of 286 tones of $\mathrm{CO}_{2}$. Carrefour also acts to help its consumers reduce their $\mathrm{CO}_{2}$ footprint by developing products with an eco-label that provides better information that aids customer choice, reducing free disposable plastic bags (to be phased out in 2012) and promoting products which are less energy consuming. Nevertheless, Carrefour does not support greenhouse gas labelling on the product because, for the group, it's only a part of the problem and it could be misleading for the consumer. The group is also focusing on eliminating its wasteful activities and increasing the recycling of waste materials in its desire to act against climate change.

\subsubsection{Sustainable supplier relationships}

\footnotetext{
${ }^{1}$ The carbon footprint as a measure, which is "the total amount of carbon dioxide $\left(\mathrm{CO}_{2}\right)$ and other greenhouse gases emitted over the entire lifecycle of a product or service" (Gereffi, 2001 p. 30). The carbon footprint is typically measured in tons of $\mathrm{CO}_{2}$ equivalents and it can be used to understand the relative amount of damage, which a product or service causes to the environment (Grenon and Turner, 2007).
} 
Carrefour declares its ambition for a 'local, sustainable and responsible supply'. The group encourages and helps its suppliers to act in a way that supports sustainability. Carrefour rewards its more engaged suppliers, in terms of sustainability, by awarding them with a ‘Trophy for Sustainability'.

Carrefour shares information and know-how and makes audits on the suppliers' performance in order to continue the progress and to help the suppliers to respond to its demands. In France, a web-tool for self-diagnosis helps suppliers of food products of private labels to improve their sustainability performance. Carrefour has developed a Social Charter that all the suppliers of private labels have to sign up in order to demonstrate their commitment to these social practices. For the year 2008, 472 social audits were conducted to verify the application of the Charter. For its part, Carrefour makes sure that is own business practices confirm to these requirements by asking its buyers to sign a Code of Conduct with an ethical hot line for the suppliers in some high risk countries. Since 2008, Carrefour has adhered to the program "Supply Chain Leadership Collaboration" of the Carbon Disclosure Project and has increased awareness of more than 500 suppliers of food products to climate change and energy efficiency requirements.

\subsubsection{Return on ecology}

Carrefour has been shown to have the best 2008 Sustainability Report highlighted by the rigor of its key indicators and the excellence of its reporting processes. Compared to 2005, the group reports in 2008 that energy consumption in stores went down by $10.5 \%$. The number of plastic bags given to consumers decreased by $33.4 \%$ and the quantity of paper bought for flyers was reduced by $8.9 \%$. Furthermore, the purchasing volume of private label bio 
products increased by $59 \%$ and the purchasing volume of fair traded products increased by $141.5 \%$.

\section{2. $\operatorname{Coop} \mathrm{A} / \mathrm{S}^{1}$}

\subsubsection{General information on the company}

Coop Danmark A/S (Coop) is Denmark's leading consumer goods retailer operating the retail chains: Kvickly xtra, Kvickly, SuperBrugsen, Dagli'Brugsen and LokalBrugsen and the subsidiaries Irma A/S and Fakta A/S. Coop, together with the cooperatives, an annual turnover of approximately EUR 670 million and employs 35,000 people.

\subsubsection{Fundamental attitude towards sustainability}

Coop has quite a lengthy history and considerable experience with environmental issues as well as social responsibility in Denmark. In the beginning of the $20^{\text {th }}$ century it was the overall goal of Coop to secure healthy and affordable food products for the average working family and small farmers in the countryside. Since the 1990's Coop has initiated an organic food initiative giving Denmark the highest per capita sales of organic food in the world. Recently Coop has introduced the '1-4-40' plan (1 vision, 4 areas, and 40 activities) with a strong focus on environment, ecology, health, climate and ethical trade.

\subsubsection{Environmental and ecological activities}

Coop has a declared environmental policy where the company states, amongst others, to reduce the environmental burden of packaging; to commit itself to active reduction of the

\footnotetext{
${ }^{1}$ This section refers to Anonymous (2010), Coop (2010) and Norden (2010)
} 
environmental burden of all activities that occur in the stores, distribution centres and during transport of goods; to make suppliers document their environmental engagement and to regularly publish the status of its environmental work as part of the annual report. Most actions in this area refer to what can be called ecological category management and ecological product development and supplier selection/collaboration.

Since the 1980's Coop has included ecological products in their assortment. Eco-labelling is used to promote the environmental engagement on the one hand, and to increase consumer trust showing that there is an alternative to a conventional product. Here, Coop uses the European Union as well as the national eco-label. Especially with the private label Änglamark, the ecological responsibility is visibly demonstrated. Under this umbrella brand Coop has been the first company in Denmark to launch an eco-labelled detergent. Moreover, Coop offers products with the eco-labels "Svanen" (the swan) and "Blomsten" (the flower). Svanen is the eco-label of the Nordic Council of Ministers indicating that the product is not harming the environment while still keeping the required quality and function. This is mainly used for household products, cleaning products and products for personal care. Blomsten is the official eco-label of the EU and also indicates a high ecological standard. Due to the many criteria that need to be met, there are not many products eco-labelled in their range yet. Within Coop, mainly textiles are labelled with this label.

\subsubsection{Carbon footprint}

Coop is not overly convinced that measuring the carbon footprint and labelling products with a climate label will help consumers to reduce their climate impact. Coop perceives the measurement of the carbon footprint as a difficult task and does not expect a valid result as all stages of the supply chain from start to finish will need to be included in the assessment of the 
carbon footprint. However, Coop has recognised that the emissions of $\mathrm{CO}_{2}$ and greenhouse gases can be reduced by careful selection of transport modes and even packaging types. Coop therefore supports the notion of food miles as a reflection of how far a product has travelled to reach the point of sale and being a better indicator of the climate burden rather than the carbon footprint.

\subsubsection{Sustainable supplier relationships}

When guaranteeing consumers fair trade products, companies are required to control their suppliers as to whether their products comply with specific requirements. Coop recognises that it is not possible to control the total supply chain at any time. However, Coop has installed certain mechanisms which allow for the compliance of ethical standards of their suppliers by supporting the Danish Initiative for Ethical Trade, the Global Compact, and the Business Social Compliance Initiative. Coop has developed a Code of Conduct that is used to observe all cooperating suppliers. Taking the non-food category as an example: Most of Coop's non-food products are manufactured in the Far East whereas all Far East suppliers have to ensure that basic worker rights are respected. All suppliers are regularly audited (both expected and unexpected) and in case a supplier is not approved, the supplier will be eliminated from the supplier base if the deficiencies are not resolved.

\subsubsection{Return on ecology}

Coop reported in its 2008 Annual Report, a $24 \%$ increase of the sales volume of ecological products, basically through the sales of the Änglamark-label. The annual report also states a $243 \%$ increase in the sales of energy saving light bulbs representing about one million bulbs 
in 2008. Looking at the Coop chain Irma, we are able to see that one fifth of the total sales volume is generated by ecological products.

\subsection{Marks and Spencer ${ }^{1}$}

\subsubsection{General information on the company}

Marks and Spencer plc (M\&S) is the major department and mixed goods retailer and the fifth larges retailer overall (after Tesco, Sainsbury's, ASDA and Wm Morrisons Supermarket) in the United Kingdom (UK). M\&S operates 668 outlets generating GBP 8,164 million (excluding sales tax) of total sales in 2009 (Mintel, 2010). The major ranges are clothing, home goods and groceries. M\&S faces increasing competition with the dominating grocery retailers and value clothing retailers such as Primark and Peacock (Mintel, 2010). M\&S has foreign operations in North America, the Far East and Ireland in the mixed goods and grocery sector. Every 10th GBP of M\&S sales comes from these markets (GBP 9.1 million).

\subsubsection{Fundamental attitude towards sustainability}

M\&S can be regarded as the precursor of ethical and sustainable retailing in the UK. This business policy is documented in 'Plan A' that was launched in 2007. It comprises 100 aims and commitments that determine how M\&S works together with its customers and supply chain partners and what the company does in terms of (1) combating climate change, (2) reduction of waste, (3) usage of sustainable raw material, (4) ethical trading and (5) supporting their customers to pursue a healthier lifestyle.

\footnotetext{
${ }^{1}$ This section refers to: Anonymous (2009), Marks and Spencers (2009), Marks and Spencers (2010) and Mintel (2010).
} 


\subsubsection{Environmental and ecological activities}

Three of the five pillars - or 64 commitments - of the M\&S 'Plan A' can be considered as environmental and ecological initiatives including climate change, waste and sustainable raw materials. The efforts to fight climate change are discussed in the next section. The actions towards the reduction of waste refer mainly to the usage of less packaging on all packaging levels as well as the reduction of one-trip shopping bags. The usage of sustainable raw material aims to use materials from only the most sustainable sources protecting the environment and the world's natural resources for future generations and encroaches on the production processes of the M\&S suppliers.

\subsubsection{Carbon footprint}

The first pillar of 'Plan A' is labelled 'climate change' and contains 29 commitments aiming to reach carbon neutrality for all UK and Irish operations by 2012. This contains the use of renewable energy and the support of supply chain partners and customers to reduce their carbon emissions. Other activities are targeted on a store level such as the increased energy efficiency of stores (and warehouses), renewal of stores including green energy generation, the $100 \%$ use of renewable energy in stores (and throughout the company) and replacement of refrigeration systems in stores by using a less damaging type of HFC gas (R407a).

In addition, a green business travel policy has also been introduced.As such green company cars are used in order to reduce $\mathrm{CO}_{2}$ emissions. M\&S helps to improve their supplier's logistics to become more efficient and encourages the use of the rail transport in contrast to air transport. Air freighted food is labelled and a carbon labelling scheme has been developed. This should help to reduce the food carbon footprint, which has been calculated at 3.3 million 
tons of $\mathrm{CO}_{2}$ in 2007 . It also contains the set up of so-called eco-factories which tie together the latest renewable energy and recycling. So far, four eco-factories which use $50 \%$ less energy and water have been opened by M\&S suppliers.

\subsubsection{Sustainable supplier relationships}

Fair supply chain partnering conduct of $M \& S$ is determined in 'Plan A' pillar 'Fair Partner'. It includes the preferences towards domestic, small suppliers (local sourcing) and towards suppliers of fair food and clothing. In comparison to 2006/07, fair-trade food sales are up by $38 \%$ which may be due to the increased offer of fair traded products. Furthermore, clear ethical guidelines for retail buyers are put in place. $M \& S$ enables and encourages information exchange between suppliers in order to communicate best practice and increase supply chain innovations. Additionally the information exchange is supported between producers and consumers with respect to the sourcing of food products. Finally, it is worth mentioning that M\&S has set up supply chain labour standards in order to address issues such as 'living wage' and working hours.

\subsubsection{Return on ecology}

It is quite difficult to judge what return of all these ethical and sustainable endeavours are for $M \& S$ since they build the basis of their entire retail operations from retail buying to merchandising. M\&S has been struggling during the recent economic downturn although remaining the fifth most powerful UK retailer. Nonetheless, this shows that UK consumers appreciate $\mathrm{M} \& \mathrm{~S}$ business policy and the ethical endeavours stated above. According to a recently published business report M\&S was prepared to invest approx. EUR 226 million realising 'Plan A' within five years (see also Environmental Leader, 2009). After two years, 
M\&S reported to have achieved 39 commitments and 24 new commitments go even further. Furthermore, 'Plan A' has become cost positive. The major achievements referred to an $18 \%$ reduction of total net $\mathrm{CO}_{2}$, a $41 \%$ recycling rate and a $10 \%$ improvement of their store energy efficiency. However, $\mathrm{M} \& \mathrm{~S}$ also shows that their total gross $\mathrm{CO}_{2}$ emissions were up by $2 \%$. The net reduction is due to the use of green electricity tariffs. It is also obvious that green logistics operations are realised by centralisation and by shifting from air freight to other transport modes.

\section{Conclusion}

In this paper we characterised the environmental supply chain management engagement of the world largest retailers. Therefore, we tried to develop a scale that can be used to measure environmental sustainable supply chain activities. Overall we can conclude that the investigated global retail Goliaths are eco-efficient Davids who transform incrementally to emerging green Goliaths.

We experienced problems in the empirical identification of our 34 constructs as retailers were not actively reporting. None of the examined retail 'Goliaths' had a full set of these initiatives and several basically reported none. This does not mean that these retailers were not engaged in environmentally beneficial endeavours, it only shows that it seems not to be worthwhile in reporting it.

Our comparison of the major results of the individual case descriptions as well as a first insight into retail specific environmental supply chain activities can be summarised as outlined in Table 5. 
Based on the available (public) information, we can see that Marks and Spencer demonstrates more efforts in environmental supply chain initiatives than the other two companies. However, following the notions of Halldorsson et al. (2009), who differ between three possible ways of how companies can incorporate sustainability in their supply chain strategy (integrate, align or replace), we would argue that all three companies align sustainability in their strategies.

This means that environmental sustainability is complementary to the traditional SCM focus on costs and service. As Halldorsson et al. (2009) further mention, an aligned sustainable SCM strategy puts equal weight on profit, service and the environment, irrespective of customers' requirements. We can see that environmental issues are part of the company's mission statement and the company accounts for all three aspects in its annual reports. Measures such as speed and reliability are replaced use of energy and material, carbon footprint and waste and landfill. An aligned strategy also focuses on co-operation and competence building in the entire supply chain. Here the observed companies are in an early stage of their activities as they claim and control that the suppliers comply with the focal company's codes of conduct. It would be necessary to co-operate with the suppliers and help them to improve the working and environment conditions.

The detailed analysis of these three selected retailers showed entirely positive results, which is a critical issue. It seems that political environmental correctness does not allow for reporting on failures or inadequate initiatives. Most of the findings refer to success stories showing that environmental goals were achieved and over-achieved. While Pearce (2009) criticises the upcoming ethnocentric sourcing strategies of large retailers, the examples of M\&S and Carrefour show that the focus on sourcing local is high in order to reduce the carbon footprint. Here Coop is different by critically assessing the value of the carbon footprint for food and 
thereby suggesting the food miles calculations. However, the downturn in economy has especially shown that the equal status of environmental and economic objectives has been disrupted.

\section{Limitations and future research}

The presented results and their interpretation need to be seen in the light of the limitation of the study. Out of the hundred selected retailers we omitted those who do not provide information in Danish, English, German or French. Further analysis could include these seemingly ethnocentric oriented market players.

Our data are derived from official and accessible documents. Internal documents and information are not considered in our analysis. Further research could focus on selected retail organisations in more depth by following a more in depth case study approach.

The focus of this paper is environmental initiatives in retail supply chains. For future research we suggest include social initiatives in the investigation in order to obtain a picture of true sustainable supply chain management of global retailers.

Nevertheless we see that our results however also put a different light on our sustainability scale, where we measured all items equally. It seems that some of the initiatives could be considered as being more important thus receiving more weight than others. This needs to be taken into account when further developing our scale. 


\section{References}

Anonymous (2009), "M\&S says sustainability 'Plan A' cash positive”, Environmental Leader, 5/6/2009, available at: http://www.environmentalleader.com/2009/06/05/ms-sayssustainability-plan-a-cash-positive/ (accessed 10 December 2010).

Anonymous (2010), "Irma er verdensmester i økologi” [Irma is world champion in ecology], Landbrugsavisen, 29/01/10, available at: http://www.landbrugsavisen.dk/Nyheder/ Netnyheder/20101/29/Irmaerverdensmesterioekologi.htm?fag=A (accessed 10 December 2010).

Biloslavo, R. and Trnavcevic, A. (2009), "Web sites as tools of communication of a "green" company", Management Decision, Vol. 47 No. 7, pp. 1158-1173

Braungart, M., McDonough, W. and Bollinger, A. (2007), “Cradle-to-cradle design: creating healthy emissions - a strategy for eco-effective product and system design, Journal of Cleaner Production, Vol. 15 No. 13-15, pp. 1337-1348.

Brunvoll, F. (2008), “Indikatorer for bærekraftig utvikling - 2008. Kan bærekraftig utvikling måles? "[Indicators for sustainable development 2008. Is it possible to measure sustainable development?], available at: http://www.ssb.no/ssp/utg/200804/02/ (accessed 10 December 2010).

Carrefour (2009), "Carrefour group sustainability report 2008”, available at:

http://www.carrefour.com/docroot/groupe/C4com/Commercepercent20responsable/Publicati ons/RGG2008GB.pdf (accessed 10 December 2010).

Carrefour (2010), “Developpement_durable” [sustainable development], available at: http://www.carrefour.fr/developpement_durable/ (accessed 10 December 2010).

Carter, C. and Jennings, M. (2002), "Logistics social responsibility: An integrative framework", Journal of Business Logistics, Vol. 23 No. 1, pp. 145-180.

Clemens, B. and Papadakis, M. (2008), "Environmental Management and Strategy in the Face of Regulatory Intensity: Radioactive Contamination in the US Steel Industry", Business Strategy and the Environment, Vol. 17 No. 8, pp. 480-492. 178003

Coop (2010), "Responsibility”, available at: http://www.coop.dk/Ansvarlighed.aspx (accessed 10 December 2010).

Deloitte/Stores Media (2008), "Global Power of Retailing”, available at: www.stores.org (accessed 10 December 2010). 
Deloitte/Stores Media (2010, “Global Power of Retailing”, available at: www.stores.org (accessed 14 March 2011).

Dobers, P. and Wolff, R. (2000), "Competing with "soft" issues - from managing the environment to sustainable business strategies", Business Strategy and the Environment, Vol. No. 9, pp. 143-150. 93002

Dunphy D, Griffiths A, Benn S (2003) Organizational change for corporate sustainability. Taylor \& Francis, London

Dyllick T. and Hockerts, K. (2002): "Beyond the business case for corporate sustainability", Business Strategy and the Environment, Vol. 11 No. 2, pp. 130-141.

Elkington J (1998) Cannibals with forks. The triple bottom line of 21 st century business. New Society Publishers

Environmental Leader (2009), “M\&S Says Sustainability 'Plan A' Cash Positive”, available at http://www.environmentalleader.com/2009/06/05/ms-says-sustainability-plan-a-cashpositive/(accessed 23 June 2010).

European Commission (2009a), "Industry. The launch of the retail forum", available at: http://ec.europa.eu/environment/industry/retail/index_en.htm (accessed 10 December 2010) European Commission (2009b), Europeans' attitudes towards the issue of sustainable consumption and production, Analytical report, Flash EB Series \# 256.

Faber, N.; Jorna, R. and Engelen, J.V. (2005), “The sustainability of sustainability - a study into the conceptual foundations of the notion of sustainability", Journal of Environmental Assessment Policy and Management, Vol. 7 No. 1, pp. 1-33.

Friedman M. (1970), «The Social Responsibility of Business is to Increase its Profits », New York Times Magazine, September 13, pp. 122-126.

Gereffi, G (2001), "Beyond the producer-driven/buyer-driven dichotomy. The evolution of global value chains in the Internet era", IDS Bull, Vol. 32 No 3, pp. 30-40.

Grankvist, G. and Biel, A. (2007), "The Impact of Environmental Information on Professional Purchasers' Choice of Products", Business Strategy and the Environment, Vol. 16 No. 6, pp421-429. 166003

Grenon, G., Martha, J. and Turner, M. (2007), "How big is your carbon footprint”, CSCMP's Supply Chain Quarterly, Vol. 1 No. 3, pp. 34-39.

Halldorsson, A., Kotzab, H. and Skjøtt-Larsen, T. (2009), "Supply chain management on the crossroad to sustainability: A blessing or a curse", Logistics Research, Vol. 1 No. 2, pp. 8394. 
Hart, S. and Ahuja, G, (1994), "Does it pay to be green? An empirical examination of the relationship between pollution prevention and firm performance", Working paper, University of Michigan, Ann Arbor.

Hockerts, K. and Wüstenhagen, R. (2010), “Greening Goliaths versus emerging Davids theorizing about the role of incumbents and new entrants in sustainable entrepreneurship", Journal of Business Venturing, Vol. 25 No. 5, pp. 481-492.

Iles, A. (2008), "Shifting To Green Chemistry: The Need for Innovations in Sustainability Marketing”, Business Strategy and the Environment, Vol. 17 No. 8, pp. 524-535. 178006

Jones, P., Comfort, D. and Hillier, D. (2004), "A case study of local food and its routes to market in the UK”, British Food Journal, Vol.106 No. 4, pp. 328-335.

Jones, P., Comfort, D. and Hillier, D. (2007a), "Corporate social responsibility: a case study of the top ten global retailers", EuroMed Journal of Business, Vol.2 No. 1, pp. 23-35.

Jones, P., Comfort, D. and Hillier, D. (2005c), “Corporate social responsibility and the UK's top ten retailers", International Journal of Retailing \& Distribution Management, Vol.33 No. 12 , pp. 882-892.

Jones, P., Comfort, D. and Hillier, D. (2007b), "Marketing and corporate social responsibility within food stores", British Food Journal, Vol.109 No. 8, pp. 582-593.

Jones, P., Comfort, D. and Hillier, D. (2008a), “Moving towards sustainable food retailing?", International Journal of Retailing \& Distribution Management, Vol.36 No. 12, pp. 9951001.

Jones, P., Comfort, D. and Hillier, D. (2008b), "UK retailing through the looking glass", International Journal of Retailing \& Distribution Management, Vol.36 No 7, pp. 564-570.

Jones, P., Comfort, D., Hillier, D. and Easwood, I. (2005b), "Retailers and sustainable development in the UK", International Journal of Retailing \& Distribution Management, Vol.33 No 3, pp. 207-214.

Jones, P., Hillier, D., Comfort, D. and Eastwood, I. (2005a), "Sustainable retailing and consumerism", Management Research News, Vol. 28 No 1, pp. 34-44.

Jönson, G. (1996), LCA: A Tool for Managing Environmental Performance, Pira International, Leatherhead.

Kotzab, H. and Madlberger, M. (2001), "European retailing in e-transition? An empirical evaluation of Web-based retailing - indications from Austria", International Journal of Physical Distribution and Logistics Management, Vol. 31 No 6, pp. 44-462. 
Læntver, R. (1993), Emnehafte: Livscyklusanalyse [Topic title: life cycle analysis], Akademisk Forlag, Copenhagen.

Larsen, G. (2006), "Why megatrends matter", available at: http://www.cifs.dk/scripts/artikel.asp?id=1469 (accessed 10 December 2010).

Larson, A. (2000), "Sustainable innovation through an entrepreneurship lens", Business Strategy and the Environment, Vol. 9 No. 5, pp. 304-317.

Lawrence, S.; Collins, E.; Pavlovich, K. and Arunachalam, M. (2006), "Sustainability Practices of SMEs: the Case of NZ", Business Strategy and the Environment, Vol. 15 No. 4, pp. 242-257. 154005

Markley, M. and Davis, L. (2007), "Exploring future competitive advantage through sustainable supply chains", International Journal of Physical Distribution \& Logistics Management, Vol. 37 No. 9, pp. 763-774.

Marks and Spencers (2009), "How we do business report. Doing the thing right", available at: http://corporate.marksandspencer.com/file.axd?pointerid=f3ccae91d1d348ff8f523ab8afe9d8 a8\&versionid=fbb46819901a428ca70ecf5a44aa8ddc (accessed 10 December 2010).

Marks and Spencers (2010), "Plan A", available at: http://plana.marksandspencer.com/ (accessed 10 December 2010).

Masurel, E. (2007), “Why SMEs Invest in Environmental Measures: Sustainability Evidence from Small and Medium-Sized Printing Firms", Business Strategy and the Environment, Vol. 16 No. 3, pp. 190-201.

Mathis, A. (2007), "Corporate Social Responsibility and Policy Making: What Role Does Communication Play?", Business Strategy and the Environment, Vol. 16 No. 5, pp. 366-385. Mintel (2010), European Retail Handbook 2009/10, Mintel, London (13 ${ }^{\text {th }}$ edition).

Nakao, Y.; Armano, A.; Matsurama, K.; Genba, K. and Nakano, M. (2007), "Relationship Between Environmental Performance and Financial Performance: an Empirical Analysis of Japanese Corporations", Business Strategy and the Environment, Vol. 16 No. 2, pp. 106118.

Norden (2010), Miljømarket Svanen [eco label the swan], available at: http://www.norden.org/en/nordic-council-of-ministers/council-of-ministers/council-ofministers-for-the-environment-mr-m/miljoemaerket-svanen (accessed 10 December 2010). Pearce, F. (2009), Confessions of an Eco Sinner: Travels to Find Where My Stuff Comes from, Transworld Publishers, London. 
Regeczi, D. (2005), “Limited Partnership: The Lack of Sustainable Development in Relation to Participation in Hungarian Public-Private Partnerships", Business Strategy and the Environment, Vol. 14 No. 4, pp. 205-215.

Srivastava, S. (2007), "Green supply-chain management: a state-of-the-art literature review”, . International Journal of Management Reviews, Vol. 9 No. 1, pp. 53-80.

Stern Review on the Economics of the Climate Change (2006), http://www.hm$\underline{\text { Treasury.gov.uk/independent_reviews/stern_review_economics_climate_change/sternreview }}$ _index.cfm (accessed, 10 December 2010).

Thomas, T (2005), “Are Business Students Buying It? A Theoretical Framework for Measuring Attitudes Toward the Legitimacy of Environmental Sustainability", Business Strategy and the Environment, Vol. 14 No. 3, pp. 186-197.

USEPA (2010), “Compliance and Enforcement Annual Results 2010 Fiscal Year”, available at: $\quad$ http://www.epa.gov/compliance/resources/reports/endofyear/eoy2010/index.html (accessed 10 December 2010)

Williander, M. (2007), “Absorptive Capacity and Interpretation System's Impact when "Going Green": an Empirical Study of Ford, Volvo Cars and Toyota", Business Strategy and the Environment, Vol. 16 No. 3, pp. 202-213. 163004 

Table 1: The environmental categories for sustainable retailing

\begin{tabular}{ll}
\hline $\begin{array}{l}\text { Environmental } \\
\text { category }\end{array}$ & Characterisation \\
\hline $\begin{array}{l}\text { Fundamental } \\
\text { environmental } \\
\text { attitude (1) }\end{array}$ & Acquire an insight into the retailer's essential standpoint on environmental issues \\
Use of energy (2) & $\begin{array}{l}\text { Survey of the measures which indicate the saving of energy and the use of more } \\
\text { environmentally friendly energy } \\
\text { Mapping the type of materials used (renewable - or non-renewable resources), where } \\
\text { the ingredients come from and whether recycled materials are used }\end{array}$ \\
$\begin{array}{l}\text { Use of input } \\
\text { material (3) }\end{array}$ & $\begin{array}{l}\text { Mapping the activities performed to make the products more environmentally friendly, } \\
\text { both in itself, but also by its usage and facilitation of reuse and recycling } \\
\text { Product (4) }\end{array}$ \\
$\begin{array}{l}\text { Mapping of accomplished activities to reduce the amount of product and transport } \\
\text { packaging and how environmentally friendly material was used }\end{array}$ \\
$\begin{array}{l}\text { Mapping the set up of distribution channels from an environmental viewpoint in order } \\
\text { to save transport kilometres in addition to assessing the transport from an } \\
\text { environmental perspective. Also, whether or not activities are performed to reduce the } \\
\text { size of a product which affects the total transport volume of the product } \\
\text { Mapping the activities that retailers carry out in order to encourage customers to } \\
\text { consume more environmentally safe products and the elimination of non-environmental } \\
\text { (word missing - benefitting) products } \\
\text { Survey the retailer's efforts to reduce material, eventually re-use of materials, including } \\
\text { cooperation with others, and dealing with clients' waste and recycling material }\end{array}$ \\
Consumption (7)
\end{tabular}


Table 2: The environmental categories for sustainable retailing (ranked in descending order by absolute number)

\begin{tabular}{|c|c|c|}
\hline $\begin{array}{l}\text { Environmental } \\
\text { category }\end{array}$ & Individual environmental initiative & $\mathrm{N}$ \\
\hline \multirow{4}{*}{$\begin{array}{l}\text { Fundamental } \\
\text { environmental } \\
\text { attitude (1) }\end{array}$} & $\begin{array}{l}\text { A. Encourage environmental responsibility and act through continuous } \\
\text { improvements throughout the supply chain }\end{array}$ & 72 \\
\hline & $\begin{array}{l}\text { B. Collaborating with other companies and organisations for environmental } \\
\text { initiatives }\end{array}$ & 57 \\
\hline & C. Support environmental standards or environmental certifications & 33 \\
\hline & D. Support environmental projects & 15 \\
\hline \multirow[t]{5}{*}{ Use of energy (2) } & A. Reducing energy and resource consumption in the buildings & 61 \\
\hline & B. Use of sustainable energy (e.g. solar or wind) & 34 \\
\hline & C. Use of new technology in transportation to reduce fuel consumption & 18 \\
\hline & D. Use of environmentally friendly fuel & 16 \\
\hline & E. Improving production in relation to used energy and resource consumption & 10 \\
\hline \multirow{4}{*}{$\begin{array}{l}\text { Use of input } \\
\text { material (3) }\end{array}$} & A. Use of renewable resources for the benefit of non-renewable resources & 33 \\
\hline & B. Use of recycled materials & 32 \\
\hline & $\begin{array}{l}\text { C. Reduced usage of raw materials that cause damage to the environment when } \\
\text { created }\end{array}$ & 18 \\
\hline & D. Use of local raw materials & 14 \\
\hline \multirow[t]{3}{*}{ Product (4) } & $\begin{array}{l}\text { A. Environmental product processes and reduction of waste in production } \\
\text { processes }\end{array}$ & 38 \\
\hline & B. Product design for reuse and recycling of materials / products & 20 \\
\hline & C. Product design for lower energy consumption when using the product & 5 \\
\hline \multirow[t]{4}{*}{ Packaging (5) } & A. Reduction of secondary packaging & 35 \\
\hline & B. Reduction of primary packaging & 33 \\
\hline & $\begin{array}{l}\text { C. Use of environmentally friendly secondary packaging that can be reused or } \\
\text { recycled }\end{array}$ & 33 \\
\hline & $\begin{array}{l}\text { D. Use of environmentally friendly primary packaging that can be reused or } \\
\text { recycled }\end{array}$ & 30 \\
\hline \multirow[t]{5}{*}{ Transport (6) } & A. Assess the distribution channel from an environmental perspective & 45 \\
\hline & $\begin{array}{l}\text { B. Reducing the number of transport-km to a minimum and smarter utilisation of } \\
\text { the transport volume }\end{array}$ & 35 \\
\hline & C. Change to more environmentally friendly transport (modal shift) & 26 \\
\hline & D. Integrated reverse logistics & 16 \\
\hline & E. Plan the size of the product's packaging to better utilise storage and transport & 10 \\
\hline \multirow[t]{3}{*}{ Consumption (7) } & $\begin{array}{l}\text { A. Encourage your customers / consumers to use environmentally friendly } \\
\text { products }\end{array}$ & 52 \\
\hline & B. Encourage customers to reuse / recycling of products / packaging & 51 \\
\hline & C. Eco-labelled products & 30 \\
\hline \multirow[t]{5}{*}{ Waste (8) } & $\begin{array}{l}\text { A. Preparing for the return of environmentally friendly products and materials / } \\
\text { containers from the store }\end{array}$ & 58 \\
\hline & B. Facilitate the handling of waste and materials for recycling from customers & 58 \\
\hline & C. Minimise waste by reusing pallets, boxes, coat hangers, etc. & 33 \\
\hline & $\begin{array}{l}\text { D. Improving opportunities for reducing waste through cooperation with other } \\
\text { actors }\end{array}$ & 30 \\
\hline & $\begin{array}{l}\text { E. Finding partners who can use materials and products the company no longer } \\
\text { needs }\end{array}$ & 18 \\
\hline
\end{tabular}




\section{Table 3 Results from the observational research}

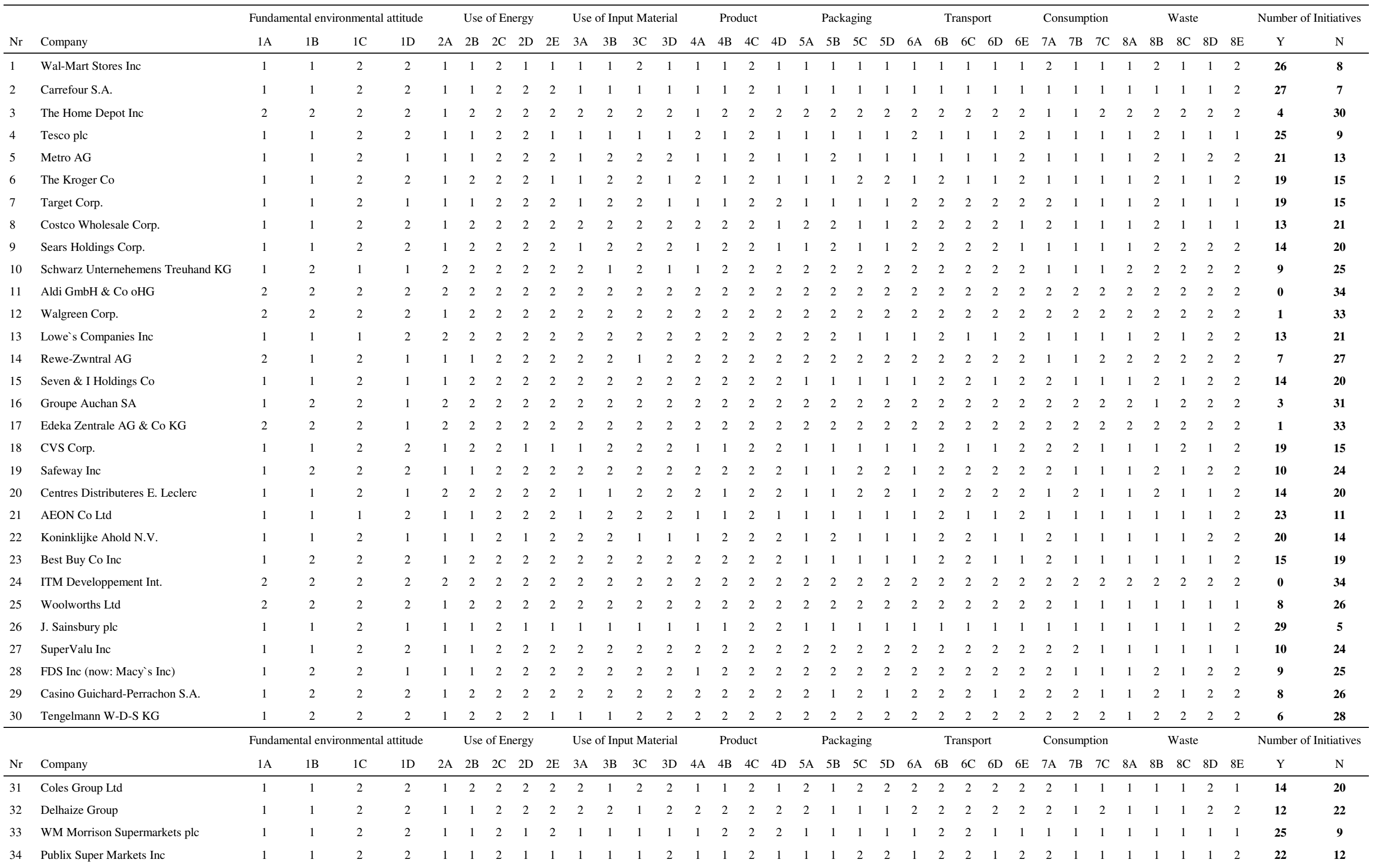




$\begin{array}{ll}35 & \text { The IKEA Group } \\ 36 & \text { Loblaw Companies Ltd } \\ 37 & \text { J. C. Penny Co Inc } \\ 38 & \text { Staples Inc } \\ 39 & \text { El Corte Ingles S.A. } \\ 40 & \text { PPR S.A. } \\ 41 & \text { Rite Aid Corp. } \\ 42 & \text { TJX Companies Inc } \\ 43 & \text { Marks \& Spencer plc } \\ 44 & \text { Kingfisher plc } \\ 45 & \text { Gap Inc } \\ 46 & \text { Kohls Corp. } \\ 47 & \text { Baugur Group hf. } \\ 48 & \text { Office Depot Inc } \\ 49 & \text { DSG International Plc } \\ 50 & \text { Mercadona S.A. } \\ 51 & \text { Coop Italia } \\ 52 & \text { Meijer Inc } \\ 53 & \text { Toys "R" Us Inc } \\ 54 & \text { AS Watson \& Company Ltd } \\ 55 & \text { Louis Delhaize S.A. } \\ 56 & \text { Circuit City Stores Inc } \\ 57 & \text { Migros-Genos-Senschafts Bund } \\ 58 & \text { Yamada Denki Co Ltd } \\ 59 & \text { Alimentation Couche-Tard Inc } \\ 60 & \text { Otto Group } \\ & \end{array}$

\begin{tabular}{|c|c|c|c|c|c|c|c|c|c|c|c|c|c|c|c|c|c|c|c|c|c|c|c|c|c|c|c|c|c|c|c|}
\hline 1 & 1 & 1 & 2 & 1 & 1 & 1 & 2 & 1 & 1 & 1 & 2 & 2 & 1 & 1 & 1 & 1 & 1 & 1 & 1 & 1 & 2 & 2 & 1 & 1 & 1 & 1 & 1 & 2 & 2 & 25 & 9 \\
\hline 1 & 1 & 2 & 1 & 1 & 1 & 1 & 2 & 2 & 2 & 2 & 2 & 1 & 1 & 1 & 1 & 1 & 1 & 1 & 2 & 1 & 2 & 1 & 1 & 1 & 1 & 2 & 1 & 2 & 2 & 22 & 12 \\
\hline 1 & 2 & 2 & 2 & 2 & 2 & 2 & 2 & 2 & 1 & 1 & 1 & 2 & 1 & 1 & 1 & 1 & 2 & 2 & 2 & 2 & 2 & 1 & 2 & 2 & 2 & 1 & 1 & 2 & 2 & 13 & 21 \\
\hline 1 & 1 & 2 & 1 & 1 & 2 & 1 & 2 & 2 & 1 & 2 & 2 & 2 & 2 & 1 & 2 & 2 & 2 & 2 & 2 & 2 & 2 & 1 & 1 & 1 & 1 & 2 & 1 & 1 & 1 & 17 & 17 \\
\hline 0 & 0 & 0 & 0 & 0 & 0 & 0 & 0 & 0 & 0 & 0 & 0 & 0 & 0 & 0 & 0 & 0 & 0 & 0 & 0 & 0 & 0 & 0 & 0 & 0 & 0 & 0 & 0 & 0 & 0 & & \\
\hline 1 & 1 & 1 & 2 & 2 & 1 & 1 & 2 & 2 & 1 & 2 & 2 & 2 & 2 & 2 & 1 & 1 & 1 & 2 & 1 & 1 & 2 & 1 & 1 & 1 & 1 & 1 & 1 & 1 & 1 & 22 & 12 \\
\hline 2 & 2 & 2 & 2 & 2 & 2 & 2 & 2 & 2 & 2 & 2 & 2 & 2 & 2 & 2 & 2 & 2 & 2 & 2 & 2 & 2 & 2 & 2 & 2 & 2 & 2 & 2 & 2 & 2 & 2 & 1 & 33 \\
\hline 1 & 2 & 2 & 2 & 2 & 2 & 2 & 2 & 2 & 1 & 2 & 2 & 2 & 2 & 2 & 1 & 1 & 1 & 2 & 2 & 1 & 2 & 2 & 2 & 2 & 2 & 1 & 2 & 2 & 2 & 8 & 26 \\
\hline 1 & 1 & 1 & 1 & 1 & 1 & 1 & 1 & 1 & 1 & 1 & 2 & 2 & 1 & 1 & 1 & 1 & 1 & 2 & 1 & 1 & 2 & 1 & 1 & 1 & 1 & 1 & 1 & 1 & 1 & 30 & 4 \\
\hline 1 & 1 & 2 & 2 & 2 & 1 & 1 & 2 & 1 & 1 & 2 & 2 & 2 & 2 & 1 & 2 & 2 & 1 & 2 & 2 & 1 & 2 & 2 & 1 & 1 & 1 & 1 & 1 & 1 & 1 & 19 & 15 \\
\hline 1 & 1 & 2 & 2 & 2 & 1 & 1 & 2 & 2 & 1 & 2 & 2 & 2 & 2 & 2 & 2 & 2 & 2 & 2 & 2 & 2 & 2 & 2 & 1 & 1 & 1 & 1 & 1 & 1 & 1 & 15 & 19 \\
\hline 1 & 1 & 2 & 1 & 2 & 1 & 1 & 2 & 2 & 1 & 2 & 2 & 2 & 2 & 2 & 2 & 2 & 1 & 1 & 1 & 1 & 2 & 2 & 1 & 1 & 1 & 2 & 1 & 2 & 2 & 17 & 17 \\
\hline 2 & 2 & 2 & 2 & 2 & 2 & 2 & 2 & 2 & 2 & 2 & 2 & 2 & 2 & 2 & 2 & 2 & 2 & 2 & 2 & 2 & 2 & 2 & 2 & 2 & 2 & 2 & 2 & 2 & 2 & 3 & 31 \\
\hline 1 & 2 & 2 & 2 & 2 & 2 & 2 & 2 & 2 & 2 & 2 & 2 & 2 & 2 & 2 & 2 & 2 & 2 & 2 & 2 & 2 & 2 & 2 & 2 & 2 & 1 & 2 & 1 & 2 & 2 & 5 & 29 \\
\hline 1 & 1 & 2 & 2 & 2 & 2 & 2 & 2 & 2 & 2 & 2 & 2 & 2 & 2 & 2 & 2 & 2 & 1 & 2 & 2 & 1 & 2 & 2 & 1 & 1 & 1 & 2 & 1 & 1 & 2 & 12 & 22 \\
\hline 1 & 2 & 2 & 2 & 2 & 2 & 2 & 2 & 2 & 1 & 1 & 2 & 2 & 1 & 2 & 1 & 2 & 1 & 2 & 1 & 1 & 1 & 2 & 2 & 2 & 1 & 1 & 1 & 2 & 2 & 14 & 20 \\
\hline 0 & 0 & 0 & 0 & 0 & 0 & 0 & 0 & 0 & 0 & 0 & 0 & 0 & 0 & 0 & 0 & 0 & 0 & 0 & 0 & 0 & 0 & 0 & 0 & 0 & 0 & 0 & 0 & 0 & 0 & & \\
\hline 2 & 2 & 2 & 1 & 2 & 2 & 2 & 2 & 2 & 2 & 2 & 2 & 2 & 2 & 2 & 2 & 2 & 1 & 2 & 2 & 1 & 2 & 2 & 1 & 2 & 2 & 2 & 2 & 2 & 2 & 6 & 28 \\
\hline 2 & 2 & 2 & 2 & 2 & 2 & 2 & 2 & 2 & 2 & 2 & 2 & 2 & 2 & 2 & 2 & 2 & 2 & 2 & 2 & 2 & 2 & 2 & 2 & 2 & 2 & 2 & 2 & 2 & 2 & 0 & 34 \\
\hline 2 & 2 & 2 & 1 & 2 & 1 & 2 & 2 & 2 & 2 & 2 & 2 & 2 & 2 & 2 & 2 & 2 & 2 & 2 & 2 & 1 & 2 & 2 & 1 & 1 & 1 & 2 & 1 & 1 & 2 & 11 & 23 \\
\hline 2 & 2 & 2 & 2 & 2 & 2 & 2 & 2 & 2 & 2 & 2 & 2 & 2 & 2 & 2 & 2 & 2 & 2 & 2 & 2 & 2 & 2 & 2 & 2 & 2 & 2 & 2 & 2 & 2 & 2 & 0 & 34 \\
\hline 2 & 2 & 2 & 2 & 2 & 2 & 2 & 2 & 2 & 2 & 2 & 2 & 2 & 2 & 2 & 2 & 2 & 2 & 2 & 2 & 2 & 2 & 2 & 2 & 2 & 2 & 2 & 2 & 2 & 2 & 0 & 34 \\
\hline 1 & 2 & 2 & 2 & 2 & 2 & 2 & 2 & 2 & 2 & 1 & 1 & 2 & 2 & 2 & 2 & 2 & 1 & 2 & 1 & 2 & 2 & 1 & 1 & 1 & 2 & 2 & 1 & 2 & 2 & 13 & 21 \\
\hline 0 & 0 & 0 & 0 & 0 & 0 & 0 & 0 & 0 & 0 & 0 & 0 & 0 & 0 & 0 & 0 & 0 & 0 & 0 & 0 & 0 & 0 & 0 & 0 & 0 & 0 & 0 & 0 & 0 & 0 & & \\
\hline 1 & 1 & 2 & 2 & 2 & 2 & 1 & 2 & 2 & 2 & 2 & 2 & 2 & 2 & 2 & 2 & 2 & 2 & 2 & 2 & 2 & 2 & 2 & 2 & 2 & 1 & 2 & 1 & 2 & 2 & 7 & 27 \\
\hline 1 & 1 & 2 & 1 & 2 & 1 & 1 & 2 & 1 & 1 & 2 & 2 & 2 & 1 & 1 & 1 & 1 & 1 & 2 & 1 & 1 & 2 & 1 & 1 & 1 & 1 & 1 & 1 & 1 & 2 & 25 & 9 \\
\hline
\end{tabular}




\begin{tabular}{|c|c|c|c|c|c|c|c|c|c|c|c|c|c|c|c|c|c|c|c|c|c|c|c|c|c|c|c|c|c|c|c|c|c|c|c|c|c|c|}
\hline \multirow[b]{2}{*}{$\mathrm{Nr}$} & \multirow[b]{2}{*}{ Company } & \multicolumn{5}{|c|}{ Fundamental environmental attitude } & \multicolumn{4}{|c|}{ Use of Energy } & \multicolumn{5}{|c|}{ Use of Input Material } & \multicolumn{3}{|c|}{ Product } & \multicolumn{4}{|c|}{ Packaging } & \multicolumn{5}{|c|}{ Transport } & & \multicolumn{4}{|c|}{ Consumption } & \multicolumn{3}{|c|}{ Waste } & \multicolumn{3}{|c|}{ Number of Initiatives } \\
\hline & & $1 \mathrm{~A}$ & $1 \mathrm{~B}$ & $1 \mathrm{C}$ & 1D & $2 \mathrm{~A}$ & $2 \mathrm{~B}$ & $2 \mathrm{C}$ & $2 \mathrm{D}$ & $2 \mathrm{E}$ & $3 \mathrm{~A}$ & $3 \mathrm{~B}$ & $3 \mathrm{C}$ & $3 \mathrm{D}$ & $4 \mathrm{~A}$ & $4 \mathrm{~B}$ & $4 \mathrm{C}$ & 4D & $5 \mathrm{~A}$ & $5 \mathrm{~B}$ & $5 \mathrm{C}$ & $5 \mathrm{D}$ & $6 \mathrm{~A}$ & $6 \mathrm{~B}$ & $6 C$ & $6 \mathrm{D}$ & $6 \mathrm{H}$ & E 7 & A 7 & 7B & 7C & $8 \mathrm{~A}$ & $8 \mathrm{~B}$ & $8 \mathrm{C}$ & $8 \mathrm{D}$ & $8 \mathrm{E}$ & $\mathrm{Y}$ & $\mathrm{N}$ \\
\hline 61 & Coop Norden AB & 1 & 1 & 2 & 1 & 1 & 2 & 2 & 2 & 2 & 2 & 2 & 2 & 2 & 1 & 2 & 2 & 2 & 1 & 1 & 1 & 1 & 1 & 2 & 2 & 2 & 2 & 2 & 1 & 1 & 2 & 2 & 2 & 2 & 2 & 2 & 12 & 22 \\
\hline 62 & Alliance Boots plc & 1 & 1 & 2 & 2 & 1 & 2 & 1 & 1 & 2 & 1 & 1 & 2 & 2 & 2 & 2 & 2 & 2 & 1 & 2 & 1 & 2 & 1 & 2 & 1 & 1 & 2 & 2 & 2 & 2 & 2 & 1 & 2 & 1 & 2 & 2 & 14 & 20 \\
\hline 63 & Sobeys Inc & 1 & 2 & 2 & 2 & 2 & 2 & 2 & 2 & 2 & 2 & 1 & 2 & 2 & 2 & 2 & 2 & 2 & 2 & 2 & 2 & 2 & 2 & 2 & 2 & 2 & 2 & 2 & 2 & 1 & 1 & 2 & 2 & 2 & 2 & 1 & 5 & 29 \\
\hline 64 & KarstadtQuelle AG (now: Arcandor AG) & 1 & 1 & 1 & 1 & 1 & 1 & 2 & 2 & 2 & 1 & 1 & 2 & 1 & 1 & 2 & 2 & 2 & 2 & 2 & 2 & 1 & 1 & 2 & 1 & 1 & 1 & 1 & 1 & 1 & 1 & 1 & 1 & 1 & 1 & 2 & 22 & 12 \\
\hline 65 & H.E. Butt Grocery Company & 1 & 1 & 1 & 2 & 1 & 1 & 2 & 2 & 1 & 2 & 1 & 2 & 2 & 2 & 2 & 2 & 2 & 2 & 2 & 2 & 2 & 1 & 2 & 2 & 2 & 2 & & 2 & 2 & 1 & 1 & 2 & 1 & 2 & 2 & 11 & 23 \\
\hline 66 & Dell Inc & 1 & 1 & 1 & 1 & 1 & 2 & 1 & 2 & 2 & 1 & 1 & 2 & 1 & 1 & 1 & 1 & 1 & 1 & 1 & 1 & 1 & 1 & 2 & 1 & 1 & 1 & 1 & 1 & 1 & 1 & 1 & 2 & 1 & 1 & 1 & 28 & 6 \\
\hline 67 & Home Retail Group plc & 1 & 1 & 2 & 1 & 1 & 1 & 2 & 1 & 2 & 1 & 1 & 2 & 1 & 1 & 1 & 1 & 1 & 1 & 1 & 1 & 1 & 1 & 1 & 2 & 1 & 1 & & 1 & 1 & 1 & 1 & 1 & 1 & 1 & 2 & 28 & 6 \\
\hline 68 & Coop & 1 & 1 & 1 & 1 & 1 & 1 & 2 & 1 & 2 & 2 & 1 & 1 & 2 & 1 & 2 & 2 & 2 & 2 & 2 & 2 & 2 & 1 & 2 & 1 & 2 & 2 & 2 & 1 & 2 & 1 & 1 & 2 & 1 & 2 & 2 & 16 & 18 \\
\hline 69 & LVMH & 1 & 1 & 2 & 1 & 1 & 2 & 1 & 2 & 1 & 1 & 2 & 2 & 2 & 1 & 2 & 2 & 1 & 1 & 2 & 1 & 2 & 1 & 2 & 1 & 2 & 2 & & 2 & 1 & 1 & 1 & 1 & 1 & 2 & 2 & 18 & 16 \\
\hline 70 & Amazon.com Inc & 2 & 2 & 1 & 2 & 2 & 2 & 2 & 2 & 2 & 2 & 2 & 2 & 2 & 2 & 2 & 2 & 2 & 2 & 2 & 2 & 2 & 2 & 2 & 2 & 2 & 2 & & 2 & 1 & 2 & 2 & 2 & 2 & 2 & 2 & 2 & 32 \\
\hline 71 & Limited Brands Inc & 1 & 1 & 2 & 2 & 1 & 2 & 2 & 2 & 2 & 1 & 1 & 2 & 1 & 1 & 2 & 2 & 2 & 1 & 2 & 1 & 1 & 1 & 1 & 1 & 1 & 1 & 1 & 2 & 1 & 1 & 1 & 1 & 1 & 1 & 1 & 22 & 12 \\
\hline 72 & John Lewis Partnership plc & 1 & 1 & 2 & 2 & 1 & 1 & 2 & 1 & 2 & 2 & 1 & 1 & 2 & 2 & 2 & 2 & 2 & 1 & 1 & 1 & 1 & 1 & 2 & 2 & 1 & 2 & 2 & 1 & 1 & 1 & 1 & 2 & 1 & 2 & 2 & 18 & 16 \\
\hline 73 & Systeme U Centrale Nationale & 0 & 0 & 0 & 0 & 0 & 0 & 0 & 0 & 0 & 0 & 0 & 0 & 0 & 0 & 0 & 0 & 0 & 0 & 0 & 0 & 0 & 0 & 0 & 0 & 0 & 0 & ) & 0 & 0 & 0 & 0 & 0 & 0 & 0 & 0 & & \\
\hline 74 & Inditex S.A. & 1 & 2 & 1 & 1 & 1 & 1 & 1 & 2 & 1 & 2 & 2 & 2 & 2 & 2 & 2 & 2 & 2 & 2 & 2 & 2 & 2 & 1 & 2 & 1 & 2 & 2 & 2 & 2 & 2 & 2 & 1 & 1 & 1 & 2 & 2 & 12 & 22 \\
\hline 75 & Uny Co ltd & 0 & 0 & 0 & 0 & 0 & 0 & 0 & 0 & 0 & 0 & 0 & 0 & 0 & 0 & 0 & 0 & 0 & 0 & 0 & 0 & 0 & 0 & 0 & 0 & 0 & 0 & ) & 0 & 0 & 0 & 0 & 0 & 0 & 0 & 0 & & \\
\hline 76 & The Jean Coutu Group (PJC) Inc & 2 & 2 & 2 & 2 & 2 & 2 & 2 & 2 & 2 & 2 & 2 & 2 & 2 & 2 & 2 & 2 & 2 & 2 & 2 & 2 & 2 & 2 & 2 & 2 & 2 & 2 & 2 & 2 & 2 & 2 & 2 & 2 & 2 & 2 & 2 & 0 & 34 \\
\hline 77 & Metro Inc & 1 & 1 & 2 & 2 & 2 & 2 & 2 & 2 & 2 & 2 & 2 & 2 & 2 & 2 & 2 & 2 & 2 & 2 & 2 & 2 & 2 & 2 & 2 & 2 & 2 & 2 & 2 & 2 & 1 & 1 & 1 & 1 & 1 & 2 & 2 & 7 & 27 \\
\hline 78 & Leroy Merlin Groupe (now: Groupe Adeo) & 1 & 2 & 2 & 2 & 1 & 2 & 2 & 2 & 2 & 2 & 2 & 2 & 2 & 1 & 2 & 2 & 2 & 2 & 2 & 2 & 2 & 2 & 2 & 2 & 2 & 2 & & 2 & 2 & 2 & 2 & 2 & 2 & 2 & 2 & 3 & 31 \\
\hline 79 & Lotte Shopping Co Ltd & 1 & 2 & 2 & 1 & 2 & 2 & 2 & 2 & 2 & 2 & 2 & 2 & 2 & 2 & 2 & 2 & 2 & 2 & 2 & 2 & 2 & 2 & 2 & 2 & 2 & 2 & 2 & 2 & 2 & 2 & 2 & 2 & 2 & 2 & 2 & 2 & 32 \\
\hline 80 & Conad Consorzio Nationale Dettaglianti & 0 & 0 & 0 & 0 & 0 & 0 & 0 & 0 & 0 & 0 & 0 & 0 & 0 & 0 & 0 & 0 & 0 & 0 & 0 & 0 & 0 & 0 & 0 & 0 & 0 & 0 & ) & 0 & 0 & 0 & 0 & 0 & 0 & 0 & 0 & & \\
\hline 81 & H\&M Hennes \& Mauritz AB & 1 & 1 & 2 & 1 & 1 & 2 & 1 & 2 & 1 & 1 & 1 & 2 & 2 & 1 & 2 & 2 & 2 & 2 & 2 & 2 & 2 & 1 & 2 & 1 & 2 & 2 & 2 & 1 & 2 & 2 & 2 & 1 & 1 & 2 & 1 & 15 & 19 \\
\hline 82 & Dollar General Corp. & 2 & 2 & 2 & 2 & 2 & 2 & 2 & 2 & 2 & 2 & 2 & 2 & 2 & 2 & 2 & 2 & 2 & 2 & 2 & 2 & 2 & 2 & 2 & 2 & 2 & 2 & 2 & 2 & 2 & 2 & 2 & 2 & 2 & 2 & 2 & $\mathbf{0}$ & 34 \\
\hline 83 & Dansk Supermarked A/S & 2 & 2 & 2 & 2 & 2 & 2 & 2 & 2 & 2 & 2 & 2 & 2 & 2 & 2 & 2 & 2 & 2 & 2 & 2 & 2 & 2 & 2 & 2 & 2 & 2 & 2 & 2 & 2 & 2 & 2 & 2 & 2 & 2 & 2 & 2 & $\mathbf{0}$ & 34 \\
\hline 84 & ICA $A B$ & 1 & 1 & 2 & 1 & 1 & 2 & 2 & 2 & 2 & 1 & 1 & 1 & 2 & 2 & 2 & 2 & 2 & 2 & 2 & 2 & 2 & 1 & 2 & 1 & 1 & 2 & 2 & 1 & 1 & 2 & 1 & 1 & 1 & 2 & 2 & 15 & 19 \\
\hline 85 & OfficeMax Inc & 1 & 1 & 2 & 2 & 1 & 1 & 1 & 2 & 1 & 1 & 1 & 2 & 1 & 1 & 1 & 1 & 1 & 2 & 2 & 2 & 2 & 1 & 2 & 2 & 2 & 2 & 2 & 2 & 1 & 1 & 1 & 1 & 1 & 2 & 1 & 20 & 14 \\
\hline 86 & SPAR Österreichische Warenhandels AG & 1 & 2 & 2 & 2 & 2 & 2 & 2 & 2 & 2 & 2 & 2 & 2 & 2 & 2 & 2 & 2 & 2 & 2 & 2 & 2 & 2 & 1 & 2 & 2 & 2 & 2 & 2 & 1 & 2 & 2 & 2 & 2 & 2 & 2 & 2 & 3 & 31 \\
\hline 87 & The Daiei Inc & 0 & 0 & 0 & 0 & 0 & 0 & 0 & 0 & 0 & 0 & 0 & 0 & 0 & 0 & 0 & 0 & 0 & 0 & 0 & 0 & 0 & 0 & 0 & 0 & 0 & 0 & ) & 0 & 0 & 0 & 0 & 0 & 0 & 0 & 0 & & \\
\hline 88 & S Group (SOK) & 1 & 2 & 2 & 2 & 2 & 2 & 2 & 2 & 2 & 2 & 2 & 2 & 2 & 2 & 2 & 2 & 2 & 2 & 2 & 2 & 2 & 2 & 2 & 2 & 2 & 2 & 2 & 2 & 2 & 2 & 2 & 2 & 2 & 2 & 2 & 1 & 33 \\
\hline 89 & Avon Products Inc & 1 & 2 & 2 & 2 & 2 & 2 & 1 & 2 & 2 & 2 & 2 & 2 & 2 & 2 & 2 & 2 & 2 & 2 & 2 & 2 & 2 & 2 & 2 & 2 & 2 & 2 & & 2 & 2 & 2 & 1 & 2 & 1 & 2 & 2 & 4 & 30 \\
\hline
\end{tabular}




\begin{tabular}{|c|c|c|c|c|c|c|c|c|c|c|c|c|c|c|c|c|c|c|c|c|c|c|c|c|c|c|c|c|c|c|c|c|c|c|c|c|c|}
\hline \multirow[b]{2}{*}{$\mathrm{Nr}$} & \multirow[b]{2}{*}{ Company } & \multicolumn{5}{|c|}{ Fundamental environmental attitude } & \multicolumn{4}{|c|}{ Use of Energy } & \multicolumn{5}{|c|}{ Use of Input Material } & \multicolumn{3}{|c|}{ Product } & \multicolumn{4}{|c|}{ Packaging } & \multicolumn{5}{|c|}{ Transport } & \multicolumn{3}{|c|}{ Consumption } & \multicolumn{4}{|c|}{ Waste } & \multicolumn{3}{|c|}{ Number of Initiatives } \\
\hline & & $1 \mathrm{~A}$ & $1 \mathrm{~B}$ & $1 \mathrm{C}$ & 1D & $2 \mathrm{~A}$ & $2 \mathrm{~B}$ & $2 \mathrm{C}$ & $2 \mathrm{D}$ & $2 \mathrm{E}$ & $3 \mathrm{~A}$ & $3 \mathrm{~B}$ & $3 \mathrm{C}$ & 3D & $4 \mathrm{~A}$ & $4 \mathrm{~B}$ & $4 \mathrm{C}$ & $4 \mathrm{D}$ & $5 \mathrm{~A}$ & $5 \mathrm{~B}$ & $5 \mathrm{C}$ & $5 \mathrm{D}$ & $6 \mathrm{~A}$ & $6 \mathrm{~B}$ & $6 \mathrm{C}$ & $6 \mathrm{D}$ & $6 \mathrm{E}$ & $7 \mathrm{~A}$ & $7 \mathrm{~B}$ & $7 \mathrm{C}$ & $8 \mathrm{~A}$ & $8 \mathrm{~B}$ & $B \quad 8 \mathrm{C}$ & $8 \mathrm{D}$ & $8 \mathrm{E}$ & $\mathrm{Y}$ & $\mathrm{N}$ \\
\hline 90 & Nordstrom Inc & 2 & 2 & 2 & 2 & 2 & 2 & 2 & 2 & 2 & 2 & 2 & 2 & 2 & 2 & 2 & 2 & 2 & 2 & 2 & 2 & 2 & 2 & 2 & 2 & 2 & 2 & 2 & 2 & 2 & 2 & 2 & 2 & 2 & 2 & $\mathbf{0}$ & 34 \\
\hline 91 & Kesko Corp. & 1 & 1 & 2 & 1 & 1 & 2 & 2 & 2 & 2 & 1 & 2 & 1 & 2 & 1 & 2 & 2 & 1 & 2 & 2 & 1 & 1 & 1 & 2 & 1 & 2 & 1 & 1 & 1 & 1 & 1 & 1 & 1 & 2 & 2 & 19 & 15 \\
\hline 92 & Shinsegae Co Ltd & 0 & 0 & 0 & 0 & 0 & 0 & 0 & 0 & 0 & 0 & 0 & 0 & 0 & 0 & 0 & 0 & 0 & 0 & 0 & 0 & 0 & 0 & 0 & 0 & 0 & 0 & 0 & 0 & 0 & 0 & 0 & 0 & 0 & 0 & & \\
\hline 93 & Army \& Air Force Exchange Service & 2 & 2 & 2 & 2 & 2 & 2 & 2 & 2 & 2 & 2 & 2 & 2 & 2 & 2 & 2 & 2 & 2 & 2 & 2 & 2 & 2 & 2 & 2 & 2 & 2 & 2 & 2 & 2 & 2 & 2 & 2 & 2 & 2 & 2 & $\mathbf{0}$ & 34 \\
\hline 94 & Kesa Electricals plc & 1 & 1 & 2 & 2 & 2 & 2 & 2 & 2 & 2 & 2 & 2 & 2 & 2 & 1 & 2 & 2 & 2 & 1 & 1 & 1 & 1 & 2 & 2 & 2 & 2 & 1 & 2 & 1 & 1 & 1 & 2 & 1 & 1 & 2 & 13 & 21 \\
\hline 95 & BJ`s Wholesale Club Inc & 2 & 2 & 2 & 2 & 2 & 2 & 2 & 2 & 2 & 2 & 2 & 2 & 2 & 2 & 2 & 2 & 2 & 2 & 2 & 2 & 2 & 2 & 2 & 2 & 2 & 2 & 2 & 2 & 2 & 2 & 2 & 2 & 2 & 2 & $\mathbf{0}$ & 34 \\
\hline 96 & Somerfield Group & 1 & 1 & 2 & 2 & 1 & 2 & 2 & 1 & 2 & 2 & 2 & 1 & 2 & 2 & 2 & 2 & 2 & 1 & 2 & 1 & 2 & 1 & 2 & 2 & 1 & 1 & 2 & 1 & 1 & 1 & 1 & 1 & 1 & 2 & 16 & 18 \\
\hline 97 & Takashimaya Company Ltd & 1 & 1 & 1 & 2 & 1 & 1 & 2 & 2 & 2 & 2 & 2 & 2 & 2 & 2 & 2 & 2 & 2 & 1 & 1 & 1 & 1 & 1 & 2 & 2 & 2 & 2 & 2 & 2 & 2 & 1 & 2 & 1 & 1 & 1 & 14 & 20 \\
\hline 98 & Fa. Anton Schlecker & 2 & 2 & 2 & 2 & 2 & 2 & 2 & 2 & 2 & 2 & 2 & 2 & 2 & 2 & 2 & 2 & 2 & 2 & 2 & 2 & 2 & 2 & 2 & 2 & 2 & 2 & 2 & 2 & 2 & 2 & 2 & 2 & 2 & 2 & $\mathbf{0}$ & 34 \\
\hline 99 & Menard Inc & 2 & 2 & 2 & 2 & 2 & 2 & 2 & 2 & 2 & 2 & 2 & 2 & 2 & 2 & 2 & 2 & 2 & 2 & 2 & 2 & 2 & 2 & 2 & 2 & 2 & 2 & 2 & 2 & 2 & 2 & 2 & 2 & 2 & 2 & $\mathbf{0}$ & 34 \\
\hline \multirow[t]{3}{*}{100} & Dillard`s Inc & 2 & 2 & 2 & 2 & 2 & 2 & 2 & 2 & 2 & 2 & 2 & 2 & 2 & 2 & 2 & 2 & 2 & 2 & 2 & 2 & 2 & 2 & 2 & 2 & 2 & 2 & 2 & 2 & 2 & 2 & 2 & 2 & 2 & 2 & $\mathbf{0}$ & 34 \\
\hline & Number of initiatives & 72 & 57 & 15 & 33 & 61 & 34 & 10 & 18 & 16 & 33 & 32 & 14 & 18 & 38 & 20 & 5 & 16 & 33 & 30 & 35 & 33 & 45 & 10 & 26 & 35 & 16 & 30 & 52 & 51 & 58 & 33 & 58 & 30 & 18 & & \\
\hline & Number of non-intiatives & 20 & 35 & 77 & 59 & 31 & 58 & 82 & 74 & 76 & 59 & 60 & 78 & 74 & 54 & 72 & 87 & 76 & 59 & 62 & 57 & 59 & 47 & 82 & 66 & 57 & 76 & 62 & 40 & 41 & 34 & 59 & 34 & 62 & 74 & & \\
\hline
\end{tabular}


Table 4: Comparison of retailing companies with the most and fewest reported environmental initiatives

\begin{tabular}{|c|c|c|c|}
\hline \multirow{2}{*}{\multicolumn{2}{|c|}{$\begin{array}{c}\text { Top } 10 \\
\text { (descending ranking based on the number of initiatives) }\end{array}$}} & \multicolumn{2}{|l|}{ Bottom 13} \\
\hline & & \multicolumn{2}{|c|}{ (alphabetically ranked) } \\
\hline Retailing company & No. of initiatives & Retailing company & No. of initiatives \\
\hline Marks \& Spencer Group plc (UK) & 30 & Aldi GmbH (D) & 0 \\
\hline J Sainsbury plc (UK) & 29 & Anton Schlecker (D) & 0 \\
\hline Home Retail Group plc (UK) & 28 & BJ's Wholesale Club (US) & 0 \\
\hline Dell Inc (US) & 28 & Circuit Stores (US) & 0 \\
\hline Carrefour S.A. (F) & 27 & Dansk Supermarked A/S (DK) & 0 \\
\hline Wal-Mart Stores (US) & 26 & Dillard's Inc. (US) & 0 \\
\hline Otto Group (D) & 25 & Dollar General Corporation (US) & 0 \\
\hline Tesco plc (UK) & 25 & ITM Developpement Int & 0 \\
\hline IKEA (S) & 25 & Louis Delhaize S.A & 0 \\
\hline \multirow[t]{5}{*}{ AEON Co Ltd. } & 23 & Menard Inc. (US) & 0 \\
\hline & & Nordstrom Inc. (US) & 0 \\
\hline & & The Jean Coutu Group (PJC) Inc & 0 \\
\hline & & Toys R Us Inc (US) & 0 \\
\hline & & Uny Co. Ltd (JP) & 0 \\
\hline
\end{tabular}




\section{Table 5: Comparison of retailing companies with the most and fewest reported environmental initiatives}

\begin{tabular}{|c|c|c|c|}
\hline Environmental issue & Coop & Marks and Spencer & Carrefour \\
\hline $\begin{array}{l}\text { Fundamental } \\
\text { sustainability attitude }\end{array}$ & $\begin{array}{l}\text { - 1-4-40 plan including } \\
\text { environment, ecology, } \\
\text { climate, health and ethical } \\
\text { trade }\end{array}$ & $\begin{array}{l}\text { - Plan A including climate } \\
\text { change, waste reduction, } \\
\text { usage of sustainable raw } \\
\text { material, ethical trading } \\
\text { and consumer lifestyle }\end{array}$ & $\begin{array}{l}\text { - Carrefour quality lines } \\
\text { - Local sourcing, local } \\
\text { development }\end{array}$ \\
\hline $\begin{array}{l}\text { Environmental and } \\
\text { ecological activities }\end{array}$ & $\begin{array}{l}\text { - Eco-labels } \\
\text { - Reduction of } \\
\text { environmental burden in } \\
\text { the supply chain } \\
\text { - Reduction of packaging } \\
\text { material } \\
\text { - Documentation by } \\
\text { suppliers and presentation } \\
\text { in annual reports }\end{array}$ & $\begin{array}{l}\text { - } 64 \text { out of } 100 \\
\text { commitments of Plan } \mathrm{A} \\
\text { - Use of less packaging } \\
\text { material } \\
\text { - Reduction of climate } \\
\text { change by } \mathrm{CO}_{2^{-}} \\
\text {management } \\
\text { - Sustainable sourcing }\end{array}$ & $\begin{array}{l}\text { - Directorate in } \\
\text { Sustainability } \\
\text { - Eco-labels } \\
\text { - Fair trade products }\end{array}$ \\
\hline Carbon Footprint & $\begin{array}{l}\text { - Follows the food miles } \\
\text { concept }\end{array}$ & $\begin{array}{l}\text { - Carbon footprint } \\
\text { calculations } \\
\text { - } 100 \% \text { use of renewable } \\
\text { energy in stores and supply } \\
\text { chain is the goal } \\
\text { - Four eco-factories }\end{array}$ & $\begin{array}{l}\text { - Energy efficiency } \\
\text { - Reduction of supply chain } \\
\text { emissions by the use of } \\
\text { waterways and railways }\end{array}$ \\
\hline $\begin{array}{l}\text { Sustainable supplier } \\
\text { relationships }\end{array}$ & - Code of Conduct & $\begin{array}{l}\text { - Fair trade policy } \\
\text { - Information exchange } \\
\text { amongst suppliers } \\
\text { - Supply chain labour } \\
\text { standards }\end{array}$ & $\begin{array}{l}\text { - Local sourcing } \\
\text { - Trophy for sustainability } \\
\text { - Code of Conduct }\end{array}$ \\
\hline Return on ecology & - Not stated & $\begin{array}{l}\text { - Total investment so far } \\
226 \text { mio EUR } \\
-18 \% \text { reduction of net } \\
\mathrm{CO}_{2}\end{array}$ & $\begin{array}{l}\text { - Not stated } \\
\text { - Indication of other KPI, } \\
e . g . \text { reduction of plastic } \\
\text { bags and energy } \\
\text { consumption }\end{array}$ \\
\hline Overall evaluation & + & +++ & ++ \\
\hline
\end{tabular}


Figure 1: Distribution of the sample on an environmental supply chain management sustainability scale

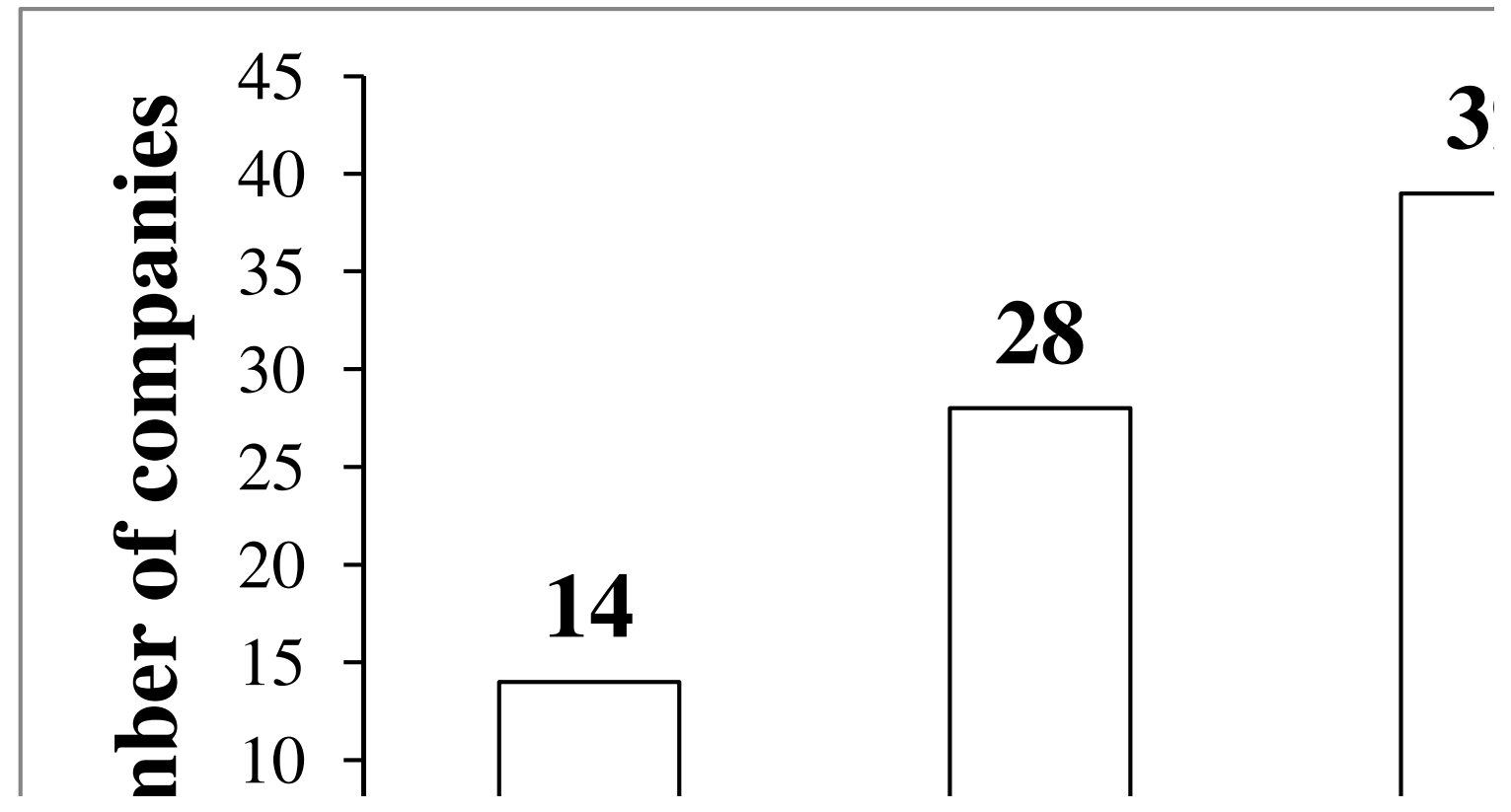

